New in paperback

\title{
Mystical Bedlam
}

Madness, Anxiety and Healing in Seventeenth-century England MICHAEL MACDONALD

Mystical Bedlam explores the social history of insanity in early seventeenth-century England by means of a detailed analysis of the records of Richard Napier, a clergyman and astrological physician, who treated over 2000 mentally disturbed patients

between 1597 and 1634. It both provides a contribution to the history of medicine and a survey of some of the darkest regions of the mental world of the seventeenthcentury English population.

\section{A Generous Confidence}

Thomas Story Kirkbride and the Art of Asylum-Keeping 1840-1883

\section{NANCY TOMES}

A Generous Confidence is a social history of medical practice in a private nineteenthcentury asylum, the Pennsylvania Hospital for the Insane in Philadelphia Besides vividly recreating everyday life in the asylum, the author concentrates on the career of Thomas Story Kirkbride, the chief physician from 1840 to 1883 , discussing his use of medical ideas, hospital design and social conventions to foster the public's 'generous confidence' in his ability to treat mental disorders.

$£ 27.50$ net

\section{Historical Origins of the Concept of Neurosis}

JOSÉ M. LOPEZ PIÑERO

Translated by D. BERRIOS

This book is the first in English to deal in depth with the historical evolution of the concept of neurosis and to show in detail its dependence upon fundamental medical concepts such as cause, function and regulation. It traces the theoretical developments from Willis and Sydenham, through Charcot and Freud, to modern times.

$\mathbf{E 1 7 . 5 0}$ net

Abridged paperback edition

\section{Mummies, Disease, and Ancient Culture The late AIDAN COCKBURN and EVE COCKBURN}

This abridged paperback edition of the Cockburns' successful book contains detailed technical descriptions of the illnesses from which people in the ancient world suffered, including physical malformations caused by poor nutrition, parasitic infestations, and vascular disorders In some, the cause of death can be determined in others, the last meal The methods of burial and mummification often offer insights into the culture and religion of the time.

Paporback 89.95 not

\section{CAMBRIDGE UNIVERSITY PRESS}




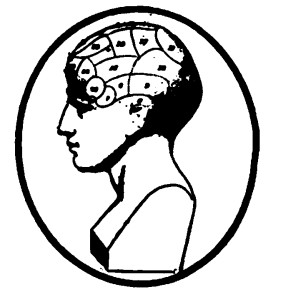

Registered Office

53 St. Martins Lane

London $\mathrm{WC}_{2}{ }_{4} \mathrm{EA}$

$01-8366040$

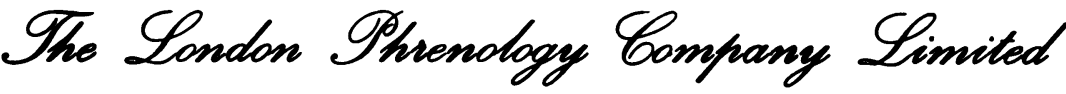

The ancient study of Phrenology has changed its expression throughout the centuries. In Victorian times it reached its zenith as a 'science' with the belief that both one's character and future could be read from the skull.

Because of the rarity and expense of Victorian Phrenological busts, the London Phrenology Company commissioned Coalport to produce a Limited Edition fine bone china replica.

These busts have been sculptured to an exquisite standard, they stand $11^{\prime \prime}$ high, on a base of 6" $x$ 6". The Faculties have been intricately delineated in black and the base is ornamented in gold.

The LPC has also published "Heads, or the Art of Phrenology", which describes how Phrenology has been developed from the ancient Ideas of Aristotle and belief in the Soul, through to Victorian Cranioscopy. It contains numerous illustrations taken from Medieval and Victorian publications, and is beautifully presented in a black \& gold semi-hard cover.

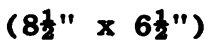

\section{Prices:}

The Phrenological Bust

U.K: $\quad$ 138* (including post, packaging and VAT)

Overseas: 1120 (including post and packing)

Heads, or the Art of Phrenology

U.K: $\quad £ 5.95$ (including post and packing)

Overseas: $£ 6.50$ (including post and packing)

Please write for further details, brochures and our discount scheme for quantity orders.

* A special price of $£ 95$ is being offered to readers of Medical History. 


\section{MEDICAL BOOKS}

Prints * Portraits

OLD, RARE,

\& OUt-OF-Print

America's Largest Stock

All items are fully catalogued and classified. American and European, dating from the 15th to the 20th centuries particularly classical and unusual works, with emphasis upon history, biography, and specialized medicine.

Lists issued in all fields of medicine.

We are eager to purchase small or large collections.

ARGOSY BOOK STORES

116 E. 59th St., N.Y., N.Y. 10022, PL. 3-4455

Rare Books \& Manuscripts in the bistory of

Medicine \& the Sciences

BOUGHT · SOLD , APPRAISED

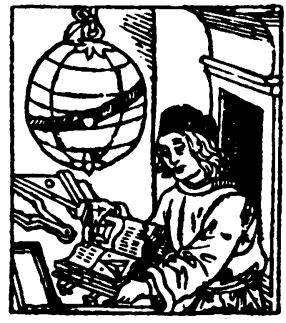

Send for our latest catalogue

Jeremy Norman \& Co., Inc.

442 POST STREET

SAN FRANCISCO, CALIFORNIA 94102 (415) $781-6402$
F. E.

Whitehart

40 Priestfield Rd.

Forest Hill

London SE23 2RS

01-699 3225 or

0689-73560

our stock

covers the

period 1500

onwards and is

devoted

exclusively to
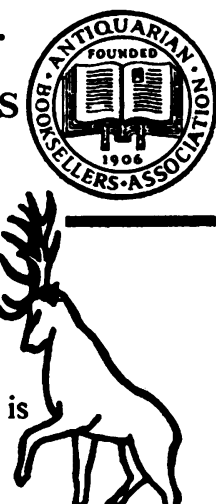

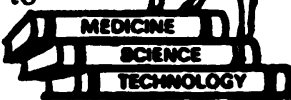

CATALOGUES ISSUED

Normal business hours or by appointment
WINTERDOWN BOOKS

\section{History of}

Medicine \& Science

Catalogue Nine includes: Learned Societies Bibliography

Catalogue Ten includes: 19th Century American Imprints

Winterdown Farm, Acrise, Folkestone, Kent CT18 8LW

Tel:(030 389) 3110 